\title{
Critical Analysis of the Law I4/20I4 on Maritime Navigation
}

\author{
Víctor L. GUTiÉRREZ CASTILLO* \& Juan J. GARCíA BLESA**
}

\begin{abstract}
The recently passed law 14/20I4 on Maritime Navigation is the most important source of regulation on this subject in Spanish law. Despite the positive impulse that this law implies in terms of a badly needed simplification and rationalization in a so far disperse and incoberent body of regulation, the approach taken by the legislator will nonetheless let down those expecting an improvement also in the technical quality of the law. In this short analysis, the authors review some of the most relevant elements of the new law and point at the main burdles that practitioners and academics might find in its application.
\end{abstract}

Passed on 24 July 2014 and published on 25 July in the Boletin Oficial del Estado (BOE, Spanish Official Journal), the Law I4/20I4 finally came into force on 25 September 2014 after a long drafting period. This is the single most important piece of maritime legislation in Spain, which regulates the basic regime governing maritime navigation and shipping in a way similar to the legislations of other EU and OECD countries. The Law establishes an all-encompassing regime that covers almost all maritime questions, including both elements of public and private law. This, as shown below, has some negative effects. However, the new Law represents an important step forward insofar as it brings to an end the prior regulation stemming from the Third Book of the 1885 Code of Commerce. This regime was not only outdated in terms of the social reality it was expected to regulate, but it also was at variance with international treaties to which Spain is a party and with other pieces of Spanish legislation.

To be sure, Spanish maritime law has evolved over time thanks to the ratification by Spain of many international treaties on the subject. However, as they were adopted these new rules entered into conflict with the outdated national legislation resulting in a body of incoherent rules scattered in several legal texts. The new Law attempts to meet these challenges and update Spanish maritime law. As stated in its preamble, the Law aims to do something more than "a mere update and codification [...]". Therefore, it undertakes to create an exhaustive framework for all activities of maritime navigation and shipping taking into account both the technological means of navigation as well as the geographic spaces on which it takes place with a view to adequately apply the international regulation.

Notwithstanding the positive aspects of this badly needed reform, the holistic approach taken by the legislative deserves some serious criticism. First, the extremely long text of the Law (524 articles) and the number of issues it governs suggest that this might in fact be an overambitious attempt. For instance, although apparently devoted to "maritime navigation", the Law also regulates issues relating

* Associate Professor of Public International Law, Universidad de Jaén, Spain.

** Research Fellow (wissenschaftlicher Mitarbeiter) at the Law School of the FernUniversität in Hagen, Germany. 
to fisheries, the protection of the marine and coastal environment, scientific research, underwater archaeology, civil liability, etc. As we are going to show, it would have been more effective to focus on navigation and shipping.

The drafting and passing of this Law has been specially long and complex. The first motion was presented in November 2004, which became a fully-fledged draft law in July 2006. In December 2008 the definitive draft law was officially put forward in the Cortes (Spanish legislative, which includes the senate and the parliament, called Congreso de los Diputados) but it was not processed. Four years later, in November 2012, the proposal was recast by the Government and presented again to the Congreso as a draft law. After several modifications and amendments to the $20 \mathrm{I} 2 \mathrm{draft},{ }^{\mathrm{r}}$ the proposal was finally passed by the Congreso on 8 July 20I4. One of the most important features of the Law is the high level of participation involving all relevant stakeholders and the wide consensus and support it has gained among these stakeholders as a result. The involvement has been especially intense in the case of businesses and business association, e.g., Asociación de Navieros Españoles (ANAVE), Pequeños $y$ Medianos Astilleros (PYMAR), Asociación Nacional de Empresas Estibadoras y Consignatarias de Buques (ANESCO), Asociación Nacional de Remolcadores de España (ANARE), Asociación Nacional de Empresas Náuticas (ANEN), Asociación Española de Grandes Yates (AEGY), Asociación Empresarial del Seguro (UNESPA), Navantia, Mapfre and many more.

The Law vows to pursue three main objectives: first, the accommodation of Spanish law to international and European maritime law due to its transnational nature; second, the guarantee of legal certainty by means of facilitating the steady and coherent interpretation and application of these international rules in Spanish domestic law; and third, the adjustment of Spanish law to the new economic and technological realities of maritime navigation and shipping. A further goal of the Law is the clear definition of the liability arising from any event or damage occurred offshore, which is now assigned to the ship owner, who is responsible for the acts and omissions of the captain and other persons under his or her command.

The regulation itself is organized according to four subject matters: the maritime environment in which navigation takes places; the means of navigation (vessels, etc.); the persons who ship the vessels; and the main activity for which the navigation is but an instrument. These four subject matters are governed by the ten titles into which the Law is divided: title I "on the administrative organization of navigation" (articles 4 through 55); title II "on the vehicles of navigation" (articles 56 through I44); title III "on the subjects of navigation" (articles 455 through I87); title IV "on the shipping contract" (articles I88 through 313); title V "on shipping third-party contractors" (articles 3I4 through 338); title VI "on navigation accidents" (articles 339 through 39I); title VII "on the limitation of liability" (articles 392 through 405); title VIII “on maritime insurance contracts" (articles 405 through 467); title IX "special procedures" (articles 468 through 500); title X "on public certification of certain maritime law expedients" (articles 50r through 524). The Law also includes ten additional provisions, two transitory provisions, one derogation provision and twelve final provisions.

The draft law was subject to 385 amendments. Exhaustive information about the debates on the law is available at <http://www.senado.es/legisio/expedientes/62I/enmiendas/index_cua_621000070.html>. 
The main source of inspiration of the Law 14/20I4 is the UN Convention on the Law of the Sea (UNCLOS), signed on Io December 1982 in Montego Bay, to which Spain is a party since 1997 (BOE No. 39, of I4 February 1997). This Convention contains, among other things, the basic international regime governing maritime policing, which is complemented by domestic law regarding state-owned ports and merchant navy. These rules are applicable to national or foreign merchant vessels that navigate or stop on Spanish waters. The application of the rules on maritime policing is generally based on a territorial criterion, without precluding the rights of the flag state. The scope of application of these rules, thus, moves between these two principles. On Spanish waters the Law will be applicable to all vessels regardless of their flag, with the limits that international and flag state law may allow. Outside Spanish waters the Law will be applied to Spanish vessels as flag state law.

The main objection to the whole statute refers to the confusing regulation of navigation provided for in title I of the Law. The Law creates distinct regimes of navigation depending on the different maritime zones established by UNCLOS; however, such regimes are not clearly defined. Instead the Law makes a general referral to the UNCLOS regulation. For instance, the navigation regime on the contiguous zone is enshrined in one single provision (article 23, "special navigation regime on the contiguous zone"), which, aside from making a vague reference to the rights of the coastal state, makes no attempt to define such regime under Spanish law. It would have been advisable to seize this opportunity to clarify the meaning of these concepts for Spanish courts and law enforcement agencies, e.g., by specifically regulating the authorization to have access to internal waters, the right to innocent passage through territorial waters, the right to transit passage through straits used for international navigation or the freedom of navigation on the exclusive economic zone - including the contiguous zone. Furthermore, a better contrast should have been introduced between the ordinary regime of innocent passage and transit passage with regard to Gibraltar. In addition, the Law establishes a further distinction concerning the navigation regime that depends on the type of vessel that navigates Spanish waters (research, fishing, submarines, etc.). This distinction, however, adds nothing to solve the above mentioned problems. Arguably, the most coherent and efficient way of regulating navigation would have been to stick to the UNCLOS maritime zone approach.

Surprisingly, the Law refers to the waters Gibraltar only twice. First, article 37 states in general that the navigation through the Strait will be governed by Part III of UNCLOS. Second, the 7th Final Provision denies any recognition of rights in favor of the United Kingdom beyond those provided for under the Treaty of Utrecht of 1713 and claims Spanish sovereignty over its waters. This is actually a legal declaration that Spain has consistently included in all pieces of domestic law and every international treaty affecting Spanish interests in relation to the Law of the Sea, for instance, when signing and ratifying the 1982 UNCLOS or prior to that in the text of the Law 1o/77 of 4 January 1977 regulating the territorial sea.

It is worth noting that the Law I4/20I4 has ignored the contradiction that exists between Spanish and International law concerning the navigation of international straits. When regulating the navigation of foreign nuclear-powered ships, Article I3 of the Law states that "[...] the regime regulating navigation as well as access to and stay at port facilities [...] will be governed by the provisions of the Law 25/1964, of 29 April, on nuclear energy and by the applicable international 
treaties". This is stated without due regard to what is provided for under Article 37 of the same Law, i.e., that "navigation through the Strait of Gibraltar is governed by Part III of the UN Convention on the Law of the Sea". The incoherence lies in the fact that the Law 25/1964 allows for the right to innocent passage of foreign nuclear-powered ships through Spanish waters to be exercised on condition of previous authorization of the Government regardless of the regime of navigation. This discrepancy between Spanish maritime law and the international law of the sea persists in articles 70 and 74 of the Law I4/2014. These provisions literally state that "national maritime authorities will be allowed to perform inspections aboard foreign nuclear-powered vessels within territorial waters and verify their safety conditions and proper functioning before they are authorized to proceed to a port or traverse national waters". Prima facie, this regime seems to be at variance with articles $22,23,24,38$ and 39 of UNCLOS.

On the other hand, the above mentioned provisions of 1964 might have been abrogated by virtue of Article 96 of the Spanish Constitution of 1978, which declares that "all international treaties validly concluded, once officially published in Spain, become a part of the internal legal order". In the face of the UNCLOS having become a part of the Spanish internal legal order since 1997, it would be difficult to maintain that the 1964 provisions to which the Law I4/20I4 refers to are still applicable. Be it as it may, the new statute could have solved such problems and clarified this regime for Spanish law enforcement agencies that might have to decide in practice whether apply these rules or not. A simple reference in one of the derogation provisions would have sufficed. The aim of such final and derogation provisions is precisely the harmonization and accommodation to the new Law of previous regimes governing, e.g., power supply, consumption, warships or the protection of the archaeological heritage of Spain. To this end, many earlier statutes are modified by the new Law, for instance, the Law I/2000 of civil procedure; also the Royal Decree (Real Decreto) 2/20II on state-owned ports and merchant navy. Even the foreseeable coming into force of the Rotterdam Rules (United Nations Convention on Contracts for the International Carriage of Goods Wholly or Partly by Sea, signed on 23 September 2009) is taken into account.

Also the use of certain terms and technical concepts in a manner inconsistent with international regulations is questionable. It is difficult to see why some new terms have been created or why old and confusing ones are used. In this vein, the use of the informal expression "Spanish maritime spaces" (articles 4, 19, 55...) which has no precedent either in Spanish or in international law is very noticeable. The expression "waters under Spanish sovereignty or jurisdiction" would have been much more appropriate. There are also constant references to "maritime internal waters" when referring to internal waters (articles I2, I8, 24, 390, ...) as though they were under a regime different from port waters (articles 16, 3I, 325, ...). It seems that the law-makers would ignore that the concept of internal waters encompasses port waters, roadstead waters and the waters of offshore port terminals. The concept of "State submarine" (article 53) is equally unheard of in international law.

In the same vein, the Law I4/20I4 lacks clarity in the wording of some basic definitions or such definitions are only partially formulated. For instance, article 5I deals with "navigation through maritime interior waters and entry to a port", but includes no reference to foreign warships, which could have been easily regulated by adopting the regime established in the Ministerial Order of 27 
March 1958 on the access of foreign warships to Spanish ports and their transit through waters under Spanish jurisdiction. Furthermore, although the definition of "ship" provided for by article 3(3) seems adequate, it would have been much simpler to draw on the definition of article 29 of the UNCLOS. Instead, in its title II the Law departs from the classical concept. The regulation of the legal status of ships begins with a definition thereof. "Ship" is a vebicle destined to navigation, wbich includes its transitory immobile or stationary situations, such as construction, anchor, aground or breaking up. This definition excludes floating maritime devices or facilities and fixed platforms for the purpose of exploiting natural resources or any other maritime activity. The main feature of a ship, therefore, is its inherent mobility and its ability to transport persons or goods of any kind. This way the Law dispenses with distinctions as to the public or private nature of the ship, or whether it serves civil, military, merchant, recreation, sports or scientific purposes. In addition, if the ship is less than 24 meters of length overall or has no deck, it will be legally considered as a "boat". This distinction between ships, boats and floating devices seems unnecessary and overcomplicated. A simple distinction between ships, including boats as recreation ships, and floating devices would have sufficed.

With regard to civil liability for accidents of navigation, title VI opens with the regulation of "boarding" by referring to the Convention for the Unification of Certain Rules of Law respecting Assistance and Salvage at Sea (Brussels, 23 September 1910). The Law further regulates liability for gross negligence and willful misconduct, excluding cases of force majeure. For the sake of third-party protection the Law establishes the joint responsibility of ship owners. This rule clarifies a topic that has been steeped in confusion for a long time due to incoherent judicial case law. The new regulation extends its scope of application to criminal and administrative procedures that deal with the determination of civil liability as a consequence of disciplinary or criminal liability. As a result, the application of the substantive regulation will not be affected by the existence of different procedural options. This simpler and clearer approach is based on the Convention on Limitation of Liability for Maritime Claims (LLMC) (London, I9 November 1976) and its 1996 Protocol.

In case of average, the Law I4/2014 follows the York-Antwerp Rules, developing those elements of the Rules that are not suitable for direct application, such as statute of limitations. A private agent appointed by the ship owner will carry out the settlement of debts originating from average. This regime is complemented by a subsidiary procedure applicable where no agreement between the parties could be reached about such debt. This complementary regime is buttressed by its reference to the 1989 International Convention on Salvage. As a result, Spanish civil courts will decide on such claims unless the parties agree to submit their issue to the maritime administrative arbitration of the Spanish Admiralty. Civil courts will also decide on cases of salvage of derelict ships or floating goods of unknown owners on the high seas. This new all-encompassing approach to salvage and the freedom given to the captain and the ship owner to establish alternative contractual regimes represent an improvement. This reform also envisages the intervention of maritime authorities in rescue and salvage operations for the purpose of protecting the marine and coastal environment. Civil liability in cases of maritime pollution and shipwrecks are also regulated in the Law in line with the international treaties ratified by Spain. 
There is also a further improvement in the regulation of ship-building and ship-purchase contracts that now rely on a better definition of the roles of ship owner and ship builder. This new regime also introduces new rules for co-ownership as well as a systematic regulation of the different types of contract for the use of a ship, including ship renting, passage, shipping contractor and towing contracts. With regard to shipping contractor contracts, the liability of the consignee or agent is excluded for damages to the cargo during the transport.

Furthermore, the Law I4/20I4 contains a number of special rules governing civil liability in case of ship or freight insurance, which allow the victim of damages to bring suit directly against the insurance company. Also third-party insurances are covered in the Law, and new procedural rules are introduced concerning the preventive seizure, forced sale, and the limited responsibility procedure. Some procedures that used to be dealt with by courts on a voluntary basis are now taken care of by notaries through procedures of public certification. Among such procedures are cargo damage claims, settlement of debt due to serious ship average, cargo consignment and shipping, loss, theft or destruction of the bill of lading, as well as the theft of cargo.

In sum, the new law on Maritime Navigation represents a step forward in the improvement of an area of regulation that was thus far extremely outdated and confusing. However, despite good intentions, the outcome could be improved, especially in relation to the navigation regime itself. The main hurdle, as pointed out above, is the deficient regulation of the different zones of navigation, which are the cornerstone of the whole regime. Furthermore, a number of issues unrelated to navigation have been included in the Law I4/20I4, e.g. the prohibition of fishing in waters under Spanish jurisdiction, the regulation of activities of scientific research or marine air traffic, which are regulated ad hoc. Finally, the Law is also riddled with rather deficient referrals and references to UNCLOS, such as in the case of the Strait of Gibraltar. 